YEARBOOK
of ANTITRUST
and REGULATORY
STUDIES
www.yars.wz.uw.edu.pl

Peer-reviewed scientific periodical, focusing on legal and economic issues of antitrust and regulation. Creative Commons Attribution-No Derivative Works 3.0 Poland License.

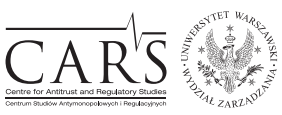

Centre for Antitrust and Regulatory Studies, University of Warsaw, Faculty of Management www.cars.wZ.uw.edu.pl

\title{
Article 108(2) TFEU as a Tool for the Commission to Bypass Article 258 TFEU Proceedings
}

\author{
by \\ Marek Rzotkiewicz*
}

\section{CONTENTS}

I. Introduction

II. The role and place of the EC in the institutional context of the EU generally and in State aid law in particular

III. Article $258 \mathrm{TFEU}$ proceedings

IV. Article 108(2) TFEU proceedings

V. Brief comments on the EC Hungarian and Polish decisions

VI. Analysis of other examples of the EC decision-making practice in light of the Hungarian and Polish decisions

VII. Conclusions

\section{Abstract}

The legal basis the European Commission (EC) choses for its actions when it finds a Member State's action (or inaction) to be in breach of its obligations stemming from its EU membership vary in different fields of law. This is particularly visible in State aid on one side, and general infringement proceedings on the other.

But the line between the general character of a possible infringement and that of State aid law is sometimes blurred and difficult to establish.

* Legal Advisor, Phd. The author works for the Faculty of Law and Administration at the University Cardinal Stefan Wyszyński in Warsaw, and for the Ministry of Foreign Affairs of the Republic of Poland, dealing with cases on State aid, as well as with cases concerning Energy law, including renewables. He acts on behalf of the Republic of Poland before the Union courts and is the author of numerous publications on EU law, both in Polish and in English. All views expressed in this text should be attributed solely to the Author and not to his employers. Comments are welcomed at m.rzotkiewicz@uksw.edu.pl. Article received: 13 June 2018; accepted: 21 September 2018. 
This article analyses if the EC does not abuse its powers when it chooses Article 108(2) TFEU, instead of Article 258 TFEU. A positive answer to that question is difficult to find and controversial. However, given the benefits the EC gains by taking action under Article 108(2) TFEU, it is visible that the EC's choice can be biased because of those benefits.

\section{Resumé}

La base juridique choisie par la Commission européenne en cas de procédures de violation des obligations du pays membre varie selon le domaine du droit. C'est particulièrement visible dans le domaine du droit des aides d'état d'un côté et en cas des procédures générales d'infraction de l'autre.

La différence entre la violation du droit des aides d'état et l'infraction de caractère général est pourtant vague et difficile à préciser.

Lobjectif de cet article est d'analyser si la Commission ne dépasse pas ses compétences en choisissant l'article 108 alinéa 2 du Traité - et non l'article 258 - comme base juridique de la procédure d'infraction. Cette analyse prend en compte des possibles avantages que la Commission peut tirer du choix de l'article 108 alinéa 2 du Traité plutôt que de l'article 258 du Traité.

Key words: State aid; infringement proceedings.

JEL: K21; K41.

\section{Introduction}

According to Article 5(1) TEU, the limits of European Union competences are governed by the principle of conferral, which refers to the granting of powers to the EU to act in a certain area. If the EU intends to take action in an area where it is not accorded power, the act taken will be ultra vires and be of no effect (Craig, 2011, p. 395). The principle of conferral also means that any action taken by the Union ${ }^{1}$ must have its legal basis (Craig and De Búrca, 2015, p. 322). This refers to any legal acts that bear legal consequences. EU legislation must be clear and its application foreseeable for all interested parties. For the sake of legal certainty, the binding nature of any act intended to have legal effects must be derived from a provision of European Union law, which prescribes the legal form to be taken by that act, and which must be expressly indicated therein as its legal basis ${ }^{2}$. Similarly, the choice of the legal

\footnotetext{
1 Opinion 2/94, EU:C:1996:140, para. 24.

2 Judgment France v. Commission, C-325/91, EU:C:1993:245, para. 26.
} 
basis for a measure may not depend simply on an institution's conviction as to the goal pursued, but must be based on objective factors which are amenable to judicial review ${ }^{3}$.

However, the mere existence of a legal basis does not suffice. Rather, it must be presented in an act taken, and the obligation to do so forms part of the duty to state reasons, an obligation deriving from Article 296 TFEU. A breach of the duty to present a statement of reasons constitutes an infringement of essential procedural requirements and may result in the annulment of an $\mathrm{act}^{4}$. A potential departure from that duty (the duty to refer to a precise provision of the Treaty) is permitted in exceptional cases, but only if the legal basis for the measure may be determined from other parts of the measure. However, an explicit reference is indispensable in cases where its absence leaves the parties concerned and the European Union courts uncertain as to the precise legal basis ${ }^{5}$.

In light of the above requirements, the question arises: How much room for manoeuvre does the European Commission (hereinafter; EC) have in its choice of a legal basis for its actions, and more specifically, when may it choose Article 108(2) TFEU proceedings instead of Article 258 TFEU proceedings for proving a Member State's infringement? However, it must be noted that this question is not about whether the EC has the right to choose one of the above legal bases (that is whichever it regards as more suitable) if an alleged breach by the Member State infringes different obligations at one and the same time, for example Article 49 TFEU on the right of establishment and, at the same time, Article 107(1) TFEU on State aid. That issue has already been answered positively, and there is no need to dwell on it in this text. The main problem posed in this text reflects a different question: Does the EC have the right to choose Article 108(2) TFEU proceedings for its actions, instead of the Article 258 TFEU proceedings, if an alleged breach objectively does not touch upon State aid rules, but the EC believes it does?

The above question has been prompted by the decisions taken by the EC in which it found Hungarian ${ }^{6}$ and Polish ${ }^{7}$ acts of Parliament to be in violation

3 Judgment Commission v Council, 45/86, EU:C:1987:163, para. 11.

4 Judgment Commission v Council, C-370/07, EU:C:2009:590, para. 62.

5 Judgment Commission v Council, 45/86, EU:C:1987:163, para. 9.

${ }^{6}$ Commission decision (EU) 2016/1846 of 04.07.2016 on the measure SA.41187 (2015/C) (ex 2015/NN) implemented by Hungary on the Health contribution of tobacco industry businesses, C(2016) 4049 final; Commission decision (EU) 2016/1848 of 04.07.2016 on the measure SA.40018 (2015/C) (ex 2015/NN) implemented by Hungary on the 2014 Amendment to the Hungarian food chain inspection fee, C(2016) 4056 final; Commission decision (EU) 2017/329 of 04.11.2016 on the measure SA.39235 (2015/C) (ex 2015/NN) implemented by Hungary on the taxation of advertisement turnover, C(2016) 6929 final.

7 Commission decision of 30.06 .2017 on the State aid SA.44351 (2016/C) (ex 2016/NN) implemented by Poland for the tax on the retail sector, C(2017) 4449 final. 
of State aid rules. But the goal of this text is not about determining which side of the dispute (the Member State or the EC respectively) is correct in its position, that is whether or not the questioned national acts really infringed upon State aid rules. Some of the abovementioned decisions have been questioned before the General Court $^{8}$ (hereinafter; GC) and have yet to be adjudged. Notwithstanding this fact, for the sake of this article the general premise is taken that the national acts questioned in the abovementioned EC decisions not only do not infringe State aid law, but they do not involve State aid at all. This premise may eventually turn out to be false based on the results of the pending judicial disputes, but that should not diminish the importance of answering the main question in this text: Does the EC have the right to choose the Article 108(2) TFEU proceedings for its actions, instead of the Article 258 TFEU proceedings, if an alleged breach objectively does not touch upon State aid rules, but the EC believes it does? That question is general in character, while the abovementioned EC decisions are given in this text only as examples.

While the question posed in this text is not easy to answer in a short article of a general nature, the answer to it may contribute to the quest for clarification of the controversy over what constitutes the real goal of the actions taken by the EC (Schohe, 2004, p. 423). Is it about the need to maintain a level playing field on the Internal Market, or does it involve a quest for the limitation of national exclusive competences?

The present article also seeks to answer the question: Do Article 108(2) TFEU proceedings grant the EC any benefits (as opposed to Article 258 TFEU proceedings) which might influence its choice? If they do not grant any such benefits for the EC, then it would seem the EC would not have any incentives whatsoever to even consider potentially bypassing Article 258 TFEU proceedings.

Based on these premises, this text analyses the following issues: the role and place of the EC in the institutional context of the EU generally and in State aid law in particular (Section II); the characteristics of Article 258 TFEU proceedings (Section III); and the characteristics of Article 108(2) TFEU proceedings (Section IV). It also offers brief comments on the Hungarian and Polish decisions (Section V), as well as strives to analyse other examples of the EC decision-making practice in light of the Hungarian and Polish decisions (Section VI). Lastly it offers conclusions (Section VII).

\footnotetext{
8 Cases T-20/17 and T-624/17.
} 


\section{The role and place of the EC in the institutional context of the EU generally and in State aid law in particular}

The general status of the EC in the institutional context of EU law is governed by the TEU and TFEU Treaties, and more specifically by the Article 17 TEU and the Articles 244-250 TFEU. The EC ensures the application of the Treaties and of measures adopted by the institutions pursuant to them. It oversees the application of European Union law under the control of the Court of Justice (hereinafter; CJ). After the entry into force of the Treaty of Lisbon, the EC maintained its previous competences under the former Article 211 TEC on the application of the Treaties and on the application of European Union law, which essentially corresponds to its role as the guardian of the Treaties. However, the EC is an EU institution and undertakes the tasks conferred upon it. Thus the EC works on behalf of the Union, and not on its own, nor on behalf of any of the Member States (Mik, 2000, p. 184).

The EC's competences are not unlimited and it has only those competences which have been conferred on it by the Member States (Schohe, 2004, p. 423). The competences conferred on the EC cannot be wider than those competences that were conferred on the Union by the Treaties, and any competences that were not conferred to the EU in the Treaties remain within the competences of the Member States. (Kosikowski, 2014, p. 168). The EC's competences should also be analysed in the context of their performance, taking into particular consideration whether these competences are exclusive EU competences, or shared with the Member States.

Within the realm of State aid law, the EC enjoys exclusive competences with respect to examining the compatibility of national measures with the Internal Market ${ }^{9}$. It is the EC's sole competence and responsibility to declare whether or not a national measure that constitutes State aid is compatible with the Internal Market ${ }^{10}$. It does not matter for that examination, nor for the scope of the EC's competences, whether an aid was granted in the form of a tax measure or in the form of a non-enforcement of a public debt held by public creditors ${ }^{11}$. Nor does it matter whether a measure under examination is covered by a competence shared with the Member State or is an exclusive competence of the Member State. Even in those instances where Member States enjoy an exclusive competence over a particular field, for instance over direct taxation, they cannot carry it out in a way that would infringe European Union law. From the formal point of view, Member States enjoy

\footnotetext{
9 Judgment Steinike \& Weinlig, 78/76, EU:C:1977:52, para. 9.

10 Judgment $P G E$, C-574/14, EU:C:2016:686, para. 32.

11 Judgment Commission v Poland, C-331/09, EU:C:2011:250, para. 7.
} 
exclusive competence over those areas that were not conferred on the Union, but this does not limit the Union's (and on its behalf the EC's) exclusive competences to examine national measures taken in those areas with respect to their compatibility with the Internal Market, as State aids.

\section{Article 258 TFEU proceedings}

When the EC finds a Member State's action (or inaction) to be in breach of its obligations stemming from its EU membership, it still has to obtain an official confirmation of that finding. The most obvious, and at the same time the most frequently used, tool for the EC to confirm a Member State's misconduct is an Article 258 TFEU proceeding (hereinafter; for the sake of this text, 'general infringement proceeding(s)'). By filing an action as a general infringement proceeding, the EC essentially seeks to obtain an official declaration from the CJ that the conduct of the Member State infringes EU law, and it seeks termination of that conduct (Lenaerts, Maselis and Gutman, 2014, p. 159).

But the general infringement proceedings themselves fulfil only the first of the above aims, as they only result in an official declaration, and do not necessarily terminate the Member State's misconduct. Although according to Article 260(1) TFEU, a judgment by the CJ obliges the Member State to take all the necessary measures to comply with the judgment, Member States often take their time to prolong the period during which they will meet their EU obligations. So it may be justifiably said that a termination of a breach is dependent on the Member State's will to follow the CJ judgment, as the CJ does not have the power in general infringement proceedings to impose specific measures to secure the effectiveness of its judgment ${ }^{12}$. Even if an action by the EC is confirmed, that is even if the CJ finds the Member State to be in breach of its European Union membership obligations, the CJ judgment confirming the general infringement proceedings is purely declaratory in nature (Lenaerts, Maselis and Gutman, 2014, p. 205). What's more, it is based on a presumption that a Member State found to be in breach of EU law will voluntarily terminate its misconduct. However, although this presumption is in theory justified under the principle of sincere cooperation stipulated in Article 4(3) TEU, in reality it is frequently a false presumption, as evidenced by the CJ case law ${ }^{13}$.

12 Judgment Commission v Germany, C-104/02, EU:C:2005:219, paras. 48-51.

13 See, e.g., judgment Commission v Portugal, C-557/14, EU:C:2016:471; judgment Commission v France, C-177/04, EU:C:2006:173; judgment Commission v Greece, C-387/97, EU:C:2000:356. 
It should be pointed out that such a judgment, even if based on a false presumption and leading only to a partial fulfilment of the EC's expectations, is nevertheless difficult to obtain. First of all, before the EC commences a general infringement proceeding, it has to undergo a long and cumbersome process which amounts to an extrajudicial phase of general infringement proceedings, during which the EC strives to clarify with the Member State all matters seen by the EC as inconsistent with EU law. Such a process is not easy for the EC, as Member States very often, if not always, maintain their position that there is no infringement from their side, and they are sometimes willing to change their position only after being presented with hard evidence. But in many instances the Member States are not willing to agree with the EC, even if they are presented with strong evidence of their misconduct. This may be understandable, as before filing an action to the CJ, the EC has to deliver a formal reasoned opinion to the Member State, which further extends the already lengthy period of time during which the Member State can play cat and mouse with the EC. Only after the Member State fails to meet the EC's expectations contained in a reasoned opinion can the EC file an action with the CJ.

But even though the judicial phase of the general infringement proceedings instituted by the EC can be finally concluded by a judgment in which the CJ finds the Member State to be in breach with its EU membership obligations, this does not yet conclude the matter, as the CJ's judgment is, as has been pointed out, only of a declaratory nature. Only after the Member State fails to fulfil an obligation to comply with such a CJ judgment can the EC bring the case before the CJ under Article 260(2) TFEU and seek an order whereby the Member State is to pay a lump sum and/or penalty payment (Peers, 2012, p. 33-64). It is only upon receipt of such a judgment of the CJ, together with the usually severe sanctions imposed ${ }^{14}$, that the EC can at last terminate the Member State's breach of EU law. But as has been shown, it is by no means easy and swift for the EC to receive such a judgment, and when the Member State does not wish to voluntarily terminate its breach of EU law, it can take many years for the EC to finally force the Member State to change its conduct. But even then there is no actual certainty that the breach has really been terminated, as there are almost always consequences of the breach that have not been remedied.

Thus it is no wonder that the effectiveness of general infringement proceedings is frequently criticised (Wennerås, 2012, p. 145-175). First of all,

14 In judgment Commission v Spain, C-278/01, EU:C:2003:635, para. 41, the CJ pointed out that the EC's suggestions cannot bind the CJ and merely constitute a useful point of reference. In exercising its discretion, it is for the CJ to fix the lump sum or penalty payment that is appropriate to the circumstances and proportionate both to the breach that has been found and to the ability to pay of the Member State concerned. 
they are ex post proceedings, which may be instituted only after a breach has (allegedly) taken place, so they cannot prevent the breaches and the principal aim of such proceedings is to terminate them. Secondly, general infringement proceedings are judicial in nature, and thus lengthy and formalistic. Thirdly, they do not protect the interests of individuals, as individuals cannot initiate such a proceeding, and the judgments in which the CJ confirms a breach of the Member State's EU obligations has no direct consequences for the rights of individuals (Munoz, 2006, p. 51).

Lastly, general infringement proceedings are known as Article 258 TFEU proceedings precisely because they are based on Article 258 TFEU, which is situated in Part Six, 'Institutional and financial provisions', Title One 'Institutional provisions', Chapter 1 'The Institutions', Section 5 'The Court of Justice of the European Union'. The rules contained in Section 5 have a general scope of application and can be regarded as lex generalis. They are applied to all matters that are not regulated specifically in other parts of the TFEU. This applies to Article 258 TFEU.

It is small wonder then, having in mind all the above factors, that even the EC regards general infringement proceedings with scepticism and seeks measures that could help it to increase its effectiveness and the effectiveness of EU law. One of such measures can be found in Article 108(2) TFEU proceedings. However, the main hurdle for the EC to use such proceedings is that such proceedings can only be used in State aid matters, and have no general application to all types of infringements of European Union law.

\section{Article 108(2) TFEU proceedings}

Unlike the general infringement proceedings, Article 108(2) TFEU proceedings can be regarded as lex specialis, which can be applied only to State aid matters. Article 108 TFEU is situated in Part Three, 'Union polices and Internal actions', Title Seven 'Common rules on competition, taxation and approximation of laws', Chapter 1 'Rules on competition', Section 2 'Aids granted by States'.

This means that the Article 258 TFEU proceedings cannot be applied for State aid matters, as they are subject to lex generalis proceedings. At the same time, this also means that in order for the EC to implement Article 108(2) TFEU proceedings to a certain infringement by a Member State, that infringement must concern State aid.

The principal aim of Article 108 TFEU, and that of the entirety of EU State aid law, is the prevention of distortions that may be caused on the Internal 
Market by the granting of an incompatible aid ${ }^{15}$. If the aid has already been granted, such proceedings are aimed at the limitation of its negative effects on the Internal Market and the restoration of the situation that existed on the market before the aid was granted (Saryusz-Wolska and Kośka, 2010, p. 163). Thus the EC may prohibit the granting of such aid by the Member State ${ }^{16}$ and/or issue an order to recover it and deprive its recipients of the benefits accruing from such aid (Jurkiewicz, 2008, p. 1176).

According to Article 108 TFEU, the EC maintains a constant review of all systems of aid existing or planned in the Member States. If the EC finds that aid granted or planned by a State is not compatible with the Internal Market, or that such aid is being misused, it can decide that the State concerned shall abolish or alter such aid within a period of time to be determined by the EC. If the State does not comply with this decision within the prescribed time, the EC may, in derogation of the provisions of Articles 258 and 259, refer the matter to the CJ. These rules are supplemented by Council Regulation No 2015/158917, according to which, if the EC finds the aid to be incompatible with the Internal Market, it shall decide that the Member State concerned shall take all the necessary measures to recover the aid from the beneficiary ${ }^{18}$. If the EC finds a State aid to be incompatible with the Internal Market, it is bound to issue the recovery order unless it would be contrary to a General principle of EU law (Rzotkiewicz, 2013, p. 464-477). These characteristics of Article 108(2) TFEU proceedings clearly demonstrate, when compared to the general infringement proceedings stipulated in Article 258 TFEU, their superiority in terms of increasing the effectiveness of EU law, even if limited in scope to State aid matters only.

First of all, in contrast to general infringement proceedings, the proceedings stipulated in Article 108(2) TFEU can be applied not only ex post but also ex ante, as they can be instituted in order to prevent the granting of an aid, not only in order to terminate it. Secondly, the EC does not have to undergo lengthy proceedings equivalent to those in the general infringement proceedings, nor does it have to ask the CJ to declare a breach of EU law by the Member State concerned. Instead, it is the EC itself which makes such a finding, and the above-mentioned examples of the EC's Hungarian

15 Judgment Saxonia Edelmetalle and ZEMAG GmbH v Commission, T-111/01 and T-133/01, EU:T:2005:166, paras. 113-114; judgment ENI-Lanerosi II, C-350/93, EU:C:1995:96, para. 22.

16 Commission decision 90/555/ECSC of 20 June 1990 concerning aid which the Italian authorities plan to grant to the Tirreno and Siderpotenza steelworks (No 195/88 - No 200/88) (OJ 1990 L 314, p. 17).

17 Council Regulation (EU) No 2015/1589 of 13 July 2015, laying down detailed rules for the application of Article 108 of the Treaty on the Functioning of the European Union (O.J. EU L 248 of 24.9.2015, p. 9), hereinafter; 'Procedural regulation'.

18 Article 16.1, first sentence, of the Procedural regulation. 
and Polish decisions clearly demonstrate that the period during which the EC can make such a finding is much shorter. Thirdly, Article 108(2) TFEU proceedings give the EC additional tools when compared to those available under general infringement proceedings.

In Article 108(2) TFEU proceedings, the EC may, making use of its power to issue administrative decisions, issue a suspension injunction, and thus force the Member State to stop the application of the measures taken by its national parliament. The EC may even issue such an injunction, albeit only 'temporary', in its decision to initiate a formal investigation procedure ${ }^{19}$. It does not need to present any evidence that the measures taken by the Member State constitute State aid incompatible with the Internal market. Moreover, the national measure does not need to be State aid at all. It's enough if the EC considers it to be State aid, that it expresses doubts as to its compatibility with the Internal Market, and that it finds it necessary to issue a suspension injunction. Thus, the EC enjoys a large degree of discretion with respect to its competence to examine the compatibility of State aid with the Internal Market.

By issuing a temporary suspension injunction, and/or by expressing its negative position in its final decision, the EC may bar the Member State from undertaking national acts the EC does not favour. It does not matter what those acts are, such as acts of Parliament, nor that they are taken within the Member State's exclusive competence, for instance measures on direct taxation.

Regardless of the negative position of the Member States in such actions (as far as concerns the choice by the EC of the kind of proceedings it wishes to pursue), the EC's actions cannot be contra legem. The EC can take actions only within the scope of the competences conferred on it. But, at the same time, it's difficult to prove that such actions are not in line with the law. In fact, such actions are taken at the outer limits of the law, which shows that Article 108(2) TFEU proceedings give the EC discernible benefits as compared to those undertaken in the context of Article 258 TFEU proceedings.

There is thus a clear difference between Article 108(2) TFEU proceedings and the general infringement proceedings. In State aid cases, the EC does not have to undergo a long and cumbersome EU PILOT procedure in order to file an action with the CJ. Neither does it have to issue a reasoned opinion (Rzotkiewicz, 2016, p. 207). This shortens the duration of the proceedings considerably. In the Hungarian decision on the Health contribution of tobacco industry businesses, only three months passed from the moment when the EC expressed its first negative comments until the date it issued a suspension injunction. In the Polish decision on the tax on the retail sector the same time period was seven months.

19 Art. 13.1 of the Procedural regulation. 
In order to achieve a comparable result using the general infringement proceedings, the EC would have had to undertake long and cumbersome proceedings before it would even be allowed to file an action with the CJ. The EC also would have had to prove that the Member State breached EU law, while in Article 108(2) TFEU proceedings the EC puts the burden of proof on the Member State to show the legality of its actions under EU law. It is the Member State which must prove that the EC decision is flawed. In addition, it is not without significance that in State aid matters the EC enjoys a wide discretion.

In sum, if the EC has to apply the general infringement proceedings, instead of Article 108(2) TFEU proceedings, the period of time before the Member State would have to terminate its actions criticised by the EC would not be three months (as in Hungarian case), but perhaps seven years or more. And its final decision issued at such a later date would not eliminate the negative effects caused by a long infringement.

Thus the benefits which Article 108(2) TFEU proceedings accord to the EC cannot be denied. It is not unreasonable to imagine that the possibility of the EC suspending the application of national measures it deems unacceptable may de facto lead to the imposition of the EC's own solutions on the Member States. In the case of the Polish decision on the tax on the retail sector, the EC made 'a suggestion' that a single (flat) tax rate on retail sales of all undertakings involved in retail trade in Poland would be compatible with the Internal Market ${ }^{20}$.

\section{Brief comments on the EC Hungarian and Polish decisions}

In both, the cases on Hungarian taxes and on the Polish tax on the retail sector, the EC, in its decisions to open the formal investigation procedure, took the preliminary view that national taxes under the EC's examination constituted State aid within the meaning of Article 107(1) TFEU. What's more, the EC stated that it had strong doubts that these measures could be declared compatible with the Internal Market. At first glance, a statement of this kind might appear peremptory, but in fact such a statement is a precondition to the issuance of a decision to initiate the formal investigation procedure. And in all the above-mentioned Hungarian and Polish cases, in its final decisions the EC has confirmed its preliminary views as to the existence of State aid in the national acts under its examination, as well as on the incompatibility of such aid with the Internal Market.

${ }^{20}$ Commission decision SA.44351, paras 49 and 54. 
At the same time, however, there are strong grounds to believe that in its above-mentioned decisions on the Hungarian taxes and on the Polish tax on the retail sector, the EC departed from its usual decision-making practice. The main argument put forward by the EC in favour of the statement that the national taxes under its examinations constituted State aid was the fact that those taxes featured progressive rates. It was not the amount or the level of the tax rates, but the very existence of progressive tax rates. This is particularly noteworthy, as the existence of progressive tax rates is not, in and of itself, regarded as a proof of the existence of State aid. Progressive tax rates are commonly used in many countries, and generally they do not raise objections as to their compatibility with the EU law on State aid. For example, the progressive turnover tax rates applied by Spain or France do not raise such doubts on the part of the EC.

While the examination of national measures as to their compatibility with the Internal Market rules on State aid is of course the sole competence of the $\mathrm{EC}$, that does not mean that in exercising its competence the EC is beyond any control ${ }^{21}$. It does mean, however, that the $\mathrm{EC}$ is well within its rights to find that the Spanish and French taxes differ from those implemented by Poland and Hungary, and that this was the main reason that the EC's findings in these cases were different. The EC is also within its rights to declare that there is a need to change its previous decision-making practice. However, the EC must, in the first instance, produce evidence in its statement of reasons demonstrating that there are such differences between the national taxes under the EC's examinations, and secondly it must explain clearly and unequivocally why it was necessary for it to depart from its earlier decision-making practice ${ }^{22}$.

The lack of clarification by the EC with respect to the existence of such evidence, or to explain the need to make a departure from its decision-making practice, raises doubts about the real goals the EC promotes in its examinations under State aid rules. Given the EC's intention to maintain a level playing field on the Internal Market, the EC should not dismiss lightly voices arguing that the taxes which it questions in some countries are similar to taxes in other countries for which the EC does not express any need for an examination. Of course one must be aware that during infringement proceedings a Member State cannot plead before the CJ that another Member State also breaches the law. However, the acceptance by the EC of such a fact (even silently, that is, by non-enforcement of State aid rules against some States) may imply that a national measure under the EC's examination is also compatible with EU State aid law. The EC is a guardian of the Treaties.

21 Judgment Buczek Automotive, T-1/08, EU:T:2011:216, para. 99; judgment Sytraval, C-367/95 P, EU:C:1998:154, para. 63.

22 Judgment Dansk Rørindustri, C-189/02 P i in., EU:C:2005:408, para. 209. 
Whatever were the genuine motives of the EC's choice of the legal basis for its actions, namely, if it was the need to eliminate the infringement caused by the Member State or if it was designed as a tool to make a Member State act in accordance with the will of the EC, it must be concluded that State aid law generally, and Article 108(2) TFEU proceedings in particular, are indeed perfect tools to attain such an aim. This may be illustrated by the suspension injunctions issued by the EC in these decisions. The very issuance of such decisions cannot be criticised by anybody, as the EC may issue them when it finds them necessary, and it is the EC which makes that decision. But at the same time such an injunction is a very exceptional tool ${ }^{23}$ with a huge impact on the Member State's interests. Therefore it should be diligently reasoned by the EC, which it failed to do in the above-mentioned decisions.

\section{Analysis of other examples of the EC decision-making practice in light of the Hungarian and Polish decisions}

The finding that Article 108(2) TFEU proceedings are indeed a perfect tool to attain goals different from those limited to maintaining a level playing field on the Internal Market, after incompatible aid is granted, and the above-mentioned doubts concerning the Hungarian and Polish decisions do not, however, warrant a general conclusion that the EC in fact sometimes, or even often, exceeds its competence by choosing Article 108(2) TFEU proceedings. In order to verify whether such a statement is accurate it is necessary to find other examples of a practice of this kind by the EC.

In the Hervis case ${ }^{24}$, which also concerned Hungarian turnover taxes with progressive rates, the EC did not express any doubts as to the compatibility of those taxes with State aid law. Although that case arose from a request for a preliminary ruling under Article 267 TFEU, and the questions put forward by the national court did not refer to Article 107(1) TFUE ${ }^{25}$, it may be assumed that that would not stop the EC from expressing its doubts if it believed, as it stated in the above-mentioned Hungarian and Polish decisions, that taxes with progressive rates generally violate State aid law.

23 Since the time when the possibility to issue a suspension injunction was stipulated in EU legislation (Regulation 659/1999), to the time when the injunction was issued in its Polish decision, the EC has issued such an injunction only eleven times.

24 Judgment Hervis Sport- és Divatkereskedelmi Kft./Nemzeti Adó- és Vámhivatal Középdunántúli Regionális Adó Fóigazgatósága, C-385/12, EU:C:2014:47.

25 They referred to Articles 18, 26, 49, 54 to 56, 63, 65 and 110 TFEU. 
The Spanish taxes, mentioned above as an example of a situation wherein the EC did not express any willingness to examine them, were also adjudged by the CJ only after a request for a preliminary ruling was put forward by a national court ${ }^{26}$. Although those taxes did not formally feature progressive tax rates, the national legislation provided that only establishments with a sales area exceeding $2500 \mathrm{~m}^{2}$ were taxed. In the above-mentioned Hungarian and Polish decisions, provisions of this kind were treated by the EC as an additional $0 \%$ tax rate benefiting entities exempted from taxation, which taken together with the other rates amounted to progressive tax rates. The Spanish tax was eventually found by the CJ not to constitute State aid, but only after Spain presented evidence that the environmental impact of retail establishments is largely dependent on their size. The larger the sales area, the higher the attendance of the public, which results in greater adverse effects on the environment. Consequently, a condition, such as that adopted by Spain, relating to sales area thresholds in order to distinguish between undertakings with a greater or lesser environmental impact was found to be consistent with the objectives pursued.

It should be noted that although the Spanish tax was eventually found not to constitute State aid, that finding was not made by the EC, which instead simply informed the complainants that it had closed its investigation and would take no further action on the complaint. It is arguable whether the conclusion adopted by the EC not to examine the case was justified, since the CJ reached its own similar conclusion only after conducting a full analysis.

Other decisions of the EC do not provide conclusive evidence whether progressive tax rates are generally regarded as a violation of State aid law, as the EC stated in the above-mentioned Hungarian and Polish decisions. But they also do not provide any evidence to the contrary, nor refute the possibility that the EC may use Article 108(2) TFEU proceedings in an abusive manner. However, from an analysis of EC decisions it seems that only in the above-mentioned cases (the Hungarian and Polish cases) has the EC reached a finding of the general selectivity of progressive tax rates. Such a conclusion is not evident in any of the decisions before the Hungarian and Polish cases, nor in any thereafter (to date). In fact, as can be seen from the EC website ${ }^{27}$, there are many national taxes with progressive tax rates that the EC does not seem to have a problem with.

${ }^{26}$ Judgment Asociación Nacional de Grandes Empresas de Distribución (ANGED)/Generalitat de Catalunya, C-233/16, EU:C:2018:280.

$27 \mathrm{http} / / /$ ec.europa.eu/taxation_customs/tedb/splSearchResult.html 


\section{Conclusions}

The above considerations justify the view that the Article 108(2) TFEU proceedings provide considerable advantages for the EC in its pursuit to terminate a Member State's infringement of EU law when compared to its tools in the general infringement proceedings. First and foremost, Article 108(2) TFEU proceedings allow the EC to terminate, in a relatively short time, the breach caused by a Member State. The above-mentioned examples of the Hungarian and Polish decisions show that it may take the EC as little as three months to issue a suspension injunction and to make the Member State terminate its conduct. In contrast, if it had used the general infringement proceedings the EC would have needed many years to force the Member State to change its actions.

The EC gains yet additional advantages by instituting Article 108(2) TFEU proceedings. It may change its legal status during a potential legal battle before the EU courts. Instead of filing an action under the general infringement proceedings with the claim that the Member State breached EU law, which the EC would have to prove, the EC may issue an administrative decision in which it simply finds a Member State's action to constitute State aid which the EC suspects to be incompatible with the Internal Market (that is, a decision to institute a formal investigation procedure). In such a decision, the EC may also include a temporary suspension injunction which, although temporary, is binding on the Member State. In addition, the Member State has to prove before the GC that the EC decision is flawed, and that by issuing it the EC itself breached EU law. The subject of the GC's examination is not the Member State's conduct, but the EC decision.

The above factors indicate that the EC may well be inclined to use Article 108(2) TFEU proceedings instead of the general infringement proceedings. Such a choice is of course limited only to those cases which may contain a State aid element. However, as the EC has the exclusive power under EU law to conduct an examination of the compatibility of State aid with the Internal Market, the EC may always say that it finds a national measure to constitute such aid, and it believes that such aid is incompatible with the Internal Market. Even if the Union courts finally rule that there was no State aid in the national measure in question, the EC may simply say it erred, but was within its competences.

Still, the current decision-making practice of the EC does not provide conclusive evidence that the EC in fact abuses its competence by choosing Article 108(2) TFEU instead of general infringement proceedings. However, given the scarcity of EC decisions in which it reached a conclusion against 
the general selectivity of progressive tax rates (only in the above-mentioned Hungarian and Polish decisions) when confronted with many national taxes with progressive tax rates (which are presented on the EC website), the obscurity of the issue remains. That obscurity is only strengthened by the lack of justification - in the statement of reasons for the above Hungarian and Polish decisions - about why the EC (for the sake of those decisions, and only those decisions) formulated a general statement against the general selectivity of all turnover taxes with progressive rates. The EC did not, in fact, provide any evidence that those decisions refer to actions different than those taken by other Member States. Therefore, although the analysis presented in this paper does not warrant a conclusive statement that the $\mathrm{EC}$ in fact abuses its powers by using Article 108(2) TFEU proceedings instead of the general infringement proceedings, it does warrant the observation that the EC may be inclined to do so because of the many advantages it thereby gains.

Thus the findings set forth above justify a premise that the manner in which the EC enjoys its competences should be closely observed.

\section{Literature}

Craig, P., (2011). The ECJ and ultra vires action: A conceptual analysis, Common Market Law Review, 48(2), 395-437.

Craig, P., De Búrca, G., (2015). EU Law. Text, Cases and Materials. Sixth Edition, Oxford University Press.

Jurkiewicz, A., (2008). Pomoc państwa [w:] Wawrzyńczak-Jędryka, B. (red.), Unia Europejska. Prawo instytucjonalne i gospodarcze. Część II. Prawo gospodarcze, Warszawa: Wolters Kluwer.

Kosikowski, C., (2014). Finanse i prawo finansowe Unii Europejskiej, Lex a Wolters Kluwer business, Warszawa 2014.

Lenaerts, K., Maselis, I., Gutman, K., (2014). The action for infringement of Union law by a Member State in Nowak J.T. (red.), EU procedural law, Oxford University Press.

Mik, C., (2000). Europejskie prawo wspólnotowe. Zagadnienia teorii i praktyki. T. 1. Warszawa: Wydawnictwo C.H. Beck.

Munoz, R., (2006). The Monitoring of the Application of Community Law: The Need to Improve the Current Tools and an Obligation to Innovate, Jean Monnet Working Paper 4.

Peers, S., (2012). Sanctions for infringement of EU law after the Treaty of Lisbon, European Public Law 1/2012, 33-64.

Rzotkiewicz, M., (2013). The General Principles of EU Law and Their Role in the Review of State Aid Put into Effect by Member States, European State Aid Law Quarterly 3/2013, 464-477. 
Rzotkiewicz, M., (2016). Wykonywanie przez Polskę decyzji Komisji Europejskiej nakazujących odzyskanie pomocy państwa w świetle prawa Unii Europejskiej, Warszawa: Urząd Ochrony Konkurencji i Konsumentów.

Saryusz-Wolska, K., Kośka, M., (2010). W poszukiwaniu utraconej skuteczności. Zasada natychmiastowego i skutecznego zwrotu pomocy państwa [w:] Kurcz B. (red.), Prawo i ekonomia konkurencji, Wybrane zagadnienia, LEX a Wolters Kluwer business.

Schohe, G., May the Commission Select the Debtor of State Aid Repayment? Where the Commission's Power over State Aid Ends, European State Aid Law Quarterly 3/2004, 423-426.

Wennerås, P., (2012). Sanctions against Member States under Article 260 TFEU: Alive, but not kicking? Common Market Law Review, 49(1), 145-175. 